\title{
CLIMATE CHANGE AND AGRICULTURE PAPER Perception of and adaptation to climate change by farmers in the Nile basin of Ethiopia
}

\author{
T. T. DERESSA ${ }^{1 *}$, R. M. HASSAN ${ }^{2}$ AND C. RINGLER ${ }^{1}$ \\ ${ }^{1}$ Environment and Production Technology Division, International Food Policy Research Institute, 2033 K Street, \\ N.W., Washington, DC 20006-1002, U.S.A. \\ ${ }^{2}$ Centre for Environmental Economics and Policy in Africa (CEEPA), Department of Agricultural Economics, \\ Faculty of Natural and Agricultural Sciences, University of Pretoria, Pretoria, South Africa
}

(Revised MS received 4 May 2010; Accepted 5 May 2010; First published online 23 August 2010)

\begin{abstract}
SUMMARY
The present study employed the Heckman sample selection model to analyse the two- step process of adaptation to climate change, which initially requires farmers' perception that climate is changing prior to responding to changes through adaptation. Farmers' perception of climate change was significantly related to the age of the head of the household, wealth, knowledge of climate change, social capital and agro-ecological settings. Factors significantly affecting adaptation to climate change were: education of the head of the household, household size, whether the head of the household was male, whether livestock were owned, the use of extension services on crop and livestock production, the availability of credit and the environmental temperature.
\end{abstract}

\section{INTRODUCTION}

Climate change affects agriculture and agriculture also affects climate change. Higher temperatures, reduced rainfall and increased rainfall variability reduce crop yield and threaten food security in low income and agriculture-based economies. Thus, the impact of climate change is detrimental to countries that depend on agriculture as the main livelihood, many located in Tropical Africa (Dixon et al. 2001; Houghton et al. 2001; IAC 2004). Agriculture affects climate change through the emission of greenhouse gases (GHG) from different farming practices (Maraseni et al. 2009; Edwards-Jones et al. 2009).

Agriculture is the main sector of the Ethiopian economy. It comprises about 0.52 of gross domestic product (GDP), employs about $0 \cdot 80$ of the population and generates more than 0.85 of the foreign exchange earnings (CSA 2005). This sector is dominated by small-scale mixed crop and livestock production, with very low productivity. The major factors responsible

To whom all correspondence should be addressed. Email: ttderessa@yahoo.com for the low productivity include reliance on traditional farming techniques, soil degradation caused by overgrazing and deforestation, poor complementary services such as extension, credit, marketing, infrastructure as well as climatic factors such as drought and flood (Devereux 2000; Alene 2003; Belay 2003; Yirga 2007). These factors reduce the adaptive capacity or increase the vulnerability of farmers to future changes, including climate change, which negatively affect the performance of the already weak agriculture.

Studies by the National Meteorological Services (Tadege 2007) indicate that the average minimum and maximum temperatures have been increasing by about $0.25^{\circ} \mathrm{C}$ and $0.1{ }^{\circ} \mathrm{C}$, respectively, over the past decade, whereas the rainfall is characterized by very high levels of variability over the past 50 years. Although models predicting precipitation give contradictory suggestions of increasing or decreasing precipitation, most climate prediction models agree that temperatures in Ethiopia will increase over the coming years (Strzepek \& McCluskey 2006). Additionally, forecasts by Tadege (2007) indicate that temperatures in Ethiopia will increase in the range of $1 \cdot 7-2 \cdot 1^{\circ} \mathrm{C}$ by the year 2050 and $2 \cdot 7-3 \cdot 4^{\circ} \mathrm{C}$ by the year 2080 . 
Moreover, studies show that the frequency and spatial coverage of drought have increased over the past few decades and this is expected to continue in the future (Lautze et al. 2003).

The fact that climate has changed in the past and will continue to change in the future underlines the need to understand how farmers perceive and adapt to climate change. Such information is necessary to guide future adaptation strategies. Studies have indicated indeed that farmers perceive that the climate is changing and also adapt to reduce the negative impacts of climate change (Thomas et al. 2007; Ishaya \& Abaje 2008; Mertz et al. 2009). Studies further show that the perception or awareness of climate change (Semenza et al. 2008; Sampei \& Aoyagi-Usui 2009; Akter \& Bennett 2009) and taking adaptive measures (Maddison 2006; Hassan \& Nhemachena 2008) are influenced by different socio-economic and environmental factors.

Some attempts have been made to analyse how farmers adapt to climate change in Ethiopia (Admassie \& Adenew 2007; Deressa \& Hassan 2009; Deressa et al. 2009). Deressa \& Hassan (2009) employed the Ricardian approach to estimate the monetary impact of climate change on Ethiopian agriculture. Even though the applied Ricardian approach includes adaptation, it does not explicitly address how farmers perceive and what adaptation methods they employ. Admassie \& Adenew (2007) studied perceptions of climate change and adaptation strategies in Ethiopia; although informative, it did not address the extent to which different socio-economic and environmental factors affect perceptions of climate change and adaptation in Ethiopia. Deressa et al. (2009) analysed the factors affecting the choice of adaptation methods, but failed to explain explicitly how farmers perceive climate change and adapt. Füssel (2007) argued that adaptation should be emphasized because human activities have already affected climate, climate change continues given past trends, the effects of emission reduction or mitigation take several decades to appear and adaptation can be undertaken at local or national levels being less dependent on the actions of others.

There are different ways of adapting to climate change in agriculture (Bradshaw et al. 2004; Kurukulasuriya \& Mendelsohn 2008; Mertz et al. 2009) and different factors affect the use of any of these adaptation methods (Nhemachena \& Hassan 2007; Deressa et al. 2009). For instance, Hassan \& Nhemachena (2008) showed that better access to markets, extension and credit services, technology, farm assets (labour, land and capital) and information about adaptation to climate change, including technological and institutional methods, affect adaptation to climate change in Africa.

Adaptation to climate change is a two-step process; the first step requires the farmers to perceive a change in climate and the second step requires them to act through adaptation (Maddison 2006). Studies on the perceptions of climate change both in developing (Vedwan \& Rhoades 2001; Hageback et al. 2005; Thomas et al. 2007; Ishaya \& Abaje 2008; Gbetibouo 2009; Mertz et al. 2009) and developed (Diggs 1991; Leiserowitz 2006; Semenza et al. 2008; Akter \& Bennett 2009) nations show that the majority of populations have already perceived climate change.

Psychometric and the cultural theory models are commonly used in analysing risk perceptions (Sjoberg 2000). Studies show that different socio-demographic factors affect the perception of climate change. For instance, Diggs (1991), Maddison (2006) and Ishaya \& Abaje (2008) showed that farming experience, which is most often associated with age, plays an important role in the perception of climate change. Studies by Sampei \& Aoyagi-Usui (2009) and Akter \& Bennett (2009) revealed that exposure to mass media increases the awareness and concern about the damage associated with climate change. Semenza et al. (2008) indicated that individuals with higher incomes are more likely to know that climate is changing than individuals with lower incomes. Moreover, other factors such as gender, ethnic background, membership of environmental groups, newspaper readers (Leiserowitz 2006), education, access to extension services, geographical site and soil types (Maddison 2006; Gbetibouo 2009) may all affect perceptions of climate change.

In developing countries, the common approach to studying the perception of farmers to climate change is based on comparing farm survey or farm group discussion results with data records from meteorological stations (Vedwan \& Rhoades 2001; Hageback et al. 2005; Thomas et al. 2007). Although informative in terms of understanding the level of awareness of farmers and the possibility of validating farmers' claims of perceptions of change against meteorological data, these approaches do not explicitly identify factors influencing awareness of climate change.

The present study is based on plausible methodological similarities among agricultural technology adoption, climate change adaptation methods and other related models which involve decisions on whether or not to adopt a given course of action and which indicate the steps economic agents take in the process of action. Agricultural technology adoption models are based on farmers' utility or profit-maximizing behaviours (Norris \& Batie 1987; Pryanishnikov \& Zigova 2003). The assumption here is that farmers adopt a new technology only when the perceived utility or profit from using this new technology is significantly greater than the traditional or the old method. While utility is not directly observed, the actions of economic agents are observed through the choices they make.

Probit and logit models are the most commonly used models in the analysis of agricultural technology 
adoption research. Binary versions are employed when the number of choices available is two (whether to adopt or not) and multivariate models are employed when the number of choices available is more than two. Multivariate models of choice have advantages (Wu \& Babcock 1998) by allowing the exploration of factors conditioning specific choices or combination of choices and also they take allow for self-selection and interactions between alternatives.

These models have also been employed in climate change studies pertaining to the conceptual similarities in agricultural technology adoption and climate change studies. For example, Nhemachena \& Hassan (2007) employed the multivariate probit model to analyse factors influencing the choice of climate change adaptation options in Southern Africa. Kurukulasuriya \& Mendelsohn (2006) employed the multinomial logit model to see if crop choice by farmers is climate sensitive. Similarly, Seo \& Mendelsohn (2006) used the multinomial logit model to analyse how the choice of livestock species is climate sensitive. Additionally, Deressa et al. (2009) adopted the multinomial logit model to analyse factors that affect the choice of adaptation methods in the Nile basin of Ethiopia.

The age of the head of the household represents experience in farming and studies have indicated that experienced farmers are more likely to perceive climate change (Maddison 2006; Ishaya \& Abaje 2008). The degree of education of the head of household is also hypothesized to be positively related to awareness of climate change. Access to information on climate change through extension agents or other sources creates awareness and favourable condition for adoption of farming practices that are suitable under climate change (Maddison 2006). Higher income positively affects public perception of climate change (Semenza et al. 2008). By the same token, it is hypothesized that higher farm and non-farm incomes positively influence farmers' perception of climate change. Farmer-to-farmer extension and the number of relatives in the Got (village) represent social capital, which plays a significant role (Isham 2002) in information exchange, and hence, it is hypothesized that social capital is associated with the perception of climate change.

The agro-ecological setting of farmers influences the perception of farmers to climate change. A study by Diggs (1991) revealed that farmers living in drier areas with more frequent droughts are more likely to describe the climate change to be warmer and drier than farmers living in a relatively wetter area with less frequent droughts. In Ethiopia, lowland areas are drier with higher drought frequency than other areas (Belay et al. 2005). Thus, it is hypothesized that farmers living in lowland areas are more likely to perceive climate change as compared to midland and highlands.
When a farmer's decision process about adoption of a new technology requires more than one step, models with two-step regressions are employed to correct for the selection bias generated during the decision-making processes. For instance, McBride \& Daberkow (2003) employed a two-step procedure (Heckman 1976) to analyse the factors affecting the awareness and adoption of new agricultural technologies in the USA. In the McBride \& Daberkow (2003) study, the first stage was an analysis of factors influencing the awareness of new technologies and the second stage was the adoption of the new technologies. Yirga (2007) and Kaliba et al. (2000) also employed Heckman's selection model to analyse the processes of agricultural technology adoption and the intensity of agricultural input use.

Maddison (2006) argued that adaptation to climate change is also a two-step process that involves perceiving that climate is changing, and then responding to changes through adaptation. Maddison (2006) addressed this two-step process of adaptation in Africa at the regional level, but the results were highly aggregated and are of little help in addressing countryspecific perceptions and adaptations to climate change.

The objective of the present study is to identify the major factors and quantify the extent to which the identified factors influence perceptions of and adaptation to climate change in the Nile Basin of Ethiopia. This information will guide policy-makers on ways to promote adaptation. It is hypothesized that different socio-economic and environmental factors affect the perceptions of and adaptation to climate change. This will be tested using data obtained from a household survey of a sample of 1000 mixed crop and livestock farmers in the Nile Basin of Ethiopia during the 2004/05 production year.

\section{MATERIALS AND METHODS}

\section{Data}

The current study is based on a cross-sectional household survey data of a total of 1000 mixed crop and livestock farmers collected during the 2004/05 production year in the Nile Basin of Ethiopia. The International Food Policy Research Institute (IFPRI) in collaboration with the Ethiopian Development Research Institute (EDRI) conducted this survey. The sample districts were purposely selected to represent different aspects of the agricultural activity in the basin including the agro-ecological zone (Dega (highlands), Woina Dega (mid-lands) and Kola (lowlands)), the degree of irrigation activity (the proportion of cultivated land), average annual rainfall, rainfall variability and population vulnerability (food aid-dependent population). 
Peasant associations (administrative units lower than districts) were also purposely selected to include households who practice irrigation. One peasant association was selected from every district (so both the number of districts and number of peasant associations was 20). Once the peasant associations were chosen, 50 farmers were randomly selected from each peasant association, making the total number of households interviewed 1000 . The temperature and rainfall data for the surveyed seasons were obtained from a global climate database developed by the University of East Anglia (Mitchell \& Jones 2005).

In addition to collecting data on different socioeconomic and environmental attributes, the survey also included information on farmers' perceptions of climate change and adaptation methods. The surveyed farmers were asked questions about their observation in the patterns of temperature and rainfall over the past 20 years.

\section{Empirical model and model variables}

\section{The empirical model}

In a two-stage process, the second stage of adaptation is a sub-sample of the first. Thus, it is likely that the second stage sub-sample (those who responded to change) is non-random and necessarily different from the first (which included those who did not perceive climate change), and this creates a sample selection bias. Therefore, a two-step maximum likelihood procedure (Heckman 1976) was used to correct for this selection bias.

Heckman's sample selection model assumes that there exists an underlying relationship which consists of the latent equation given by:

$$
y_{j}^{*}=x_{j} \beta+u_{1 j}
$$

where $y_{j}{ }^{*}$ is the latent variable (the propensity to adapt to climate change), $x$ is a $k$-vector of explanatory variables, which include different factors hypothesized to affect adaptation, $\beta$ is the parameter estimate and $u_{1 j}$ is an error term. Therefore, only the binary outcome given by the probit model is observed as

$$
y_{j}^{\text {probit }}=\left(y_{j}^{*}>0\right)
$$

The dependent variable is observed only if the observation $j$ is observed in the selection equation:

$$
\begin{aligned}
y_{j}^{\text {select }} & =\left(z_{j} \delta+u_{2 j}>0\right) \\
u_{1} & \sim N(0,1) \\
u_{2} & \sim N(0,1) \\
& \operatorname{corr}\left(u_{1}, u_{2}\right)=\rho
\end{aligned}
$$

where $y_{j}^{\text {select }}$ is whether a farmer has perceived climate change or not, $z$ is an $\mathbf{m}$ vector of explanatory variables, which include different factors hypothesized to affect perception; $\delta$ is the parameter estimate, $u_{2 j}$ is an error term and $u_{1}$ and $u_{2}$ are error terms, which are normally distributed with mean zero and variance one. Thus, the first stage of Heckman's two-step model is the selection model (eqn 3), which represents the perception of changes in climate. The second stage is the outcome model (eqn 1), which represents whether the farmer adapted to climate change, and is conditional upon whether this has been perceived.

When the error terms from the selection and the outcome equations are correlated or when $\rho \neq 0$, standard probit techniques applied to eqn (1) yield biased results. Thus, the Heckman probit provides consistent, asymptotically efficient estimates for all parameters in such models (Van de Ven \& Van Praag 1981). Hence, the Heckman probit selection model is employed to analyse the perception and adaptation to climate change in the Nile Basin of Ethiopia.

The dependent variable for the selection equation is whether a farmer has or has not perceived climate change. The explanatory variables for the selection equation include different socio-demographic and environmental factors based on the literature on factors affecting the awareness of farmers to climate change or their risk perceptions. It is hypothesized that the age and education of the head of the household, information on climate, farmer to farmer extension, number of relatives in the Got (village), farm and nonfarm incomes and agro-ecological settings influence the awareness of farmers to climate change.

The dependent variable for the outcome equation is whether a farmer has adapted or not to climate change. The explanatory variables are chosen based on the climate change adaptation literature and data availability. These variables include: education of the head of the household, household size, gender of the head of the household, non-farm income, livestock ownership, extension on crop and livestock production, access to credit, farm size, distance to input and output markets, temperature and precipitation. Detailed descriptions of the hypothetical relationships between these variables and adaptation to climate change are described in Hassan \& Nhemachena (2007), Deressa et al. (2009) and Nhemachena (2009). Tables 1 and 2 give the descriptions of model variables for the Heckman probit selection model.

\section{RESULTS}

The results indicated that $0 \cdot 51$ of the surveyed farmers perceived increasing temperatures, and 0.53 perceived decreasing rainfall over the past 20 years (Figs 1 and 2). The average minimum and maximum temperatures have increased by $c .0 \cdot 25^{\circ} \mathrm{C}$ and $0 \cdot 1{ }^{\circ} \mathrm{C}$, respectively, over the past decade (Tadege 2007).

Those farmers who claimed to have observed changes in climate over the past 20 years were 
Table 1. Description of model variables of the outcome equation for the Heckman probit selection model

(a) Dependent variable

Description

Farmers who

Farmers who did not adapted (proportion) adapt (proportion)

Adaptation to climate change (dummy: takes the

$0 \cdot 58$

$0 \cdot 42$

value of 1 if adapted and 0 otherwise)

(b) Independent variables

Description

Mean

Education of the household head in years (continuous)

Size of the household (continuous)

Gender (dummy: 1 if male otherwise 0)

Non-farm income in Ethiopian currency (continuous)

Livestock ownership (dummy: 1 if livestock owned otherwise 0 )

Extension advice on crop and livestock (dummy: 1 if visited otherwise 0 )

Credit (dummy: 1 if there is access otherwise 0)

Farm size (ha; continuous)

Distance to output market ( $\mathrm{km}$; continuous)

Distance to input market (km; continuous)

Temperature ( ${ }^{\circ} \mathrm{C}$ continuous: annual average over the $2004 / 05$ survey period)

Precipitation (mm; continuous: annual average over the 2004/05 survey period)

$1 \cdot 7$

\section{$6 \cdot 1$}

$0 \cdot 9$

218

$0 \cdot 9$

$0 \cdot 5$

$0 \cdot 2$

$2 \cdot 0$

$5 \cdot 7$

$5 \cdot 6$

$18 \cdot 6$

$115 \cdot 6$
S.D.

$2 \cdot 8$

$2 \cdot 2$

$0 \cdot 3$

791

$0 \cdot 2$

$0 \cdot 5$

$0 \cdot 4$

$1 \cdot 2$

$4 \cdot 1$

$4 \cdot 2$

$1 \cdot 3$

$35 \cdot 6$

Table 2. Description of model variables of the selection equation for the Heckman probit selection model

(a) Dependent variable

Description
$\begin{gathered}\text { Farmers who } \\
\text { perceived change } \\
\text { (proportion) }\end{gathered}$ \begin{tabular}{c}
$\begin{array}{c}\text { Farmers who did not } \\
\text { perceive change } \\
\text { (proportion) }\end{array}$ \\
\hline
\end{tabular}

Perception of climate change

(dummy: takes the value of 1 if perceived and 0 otherwise)

$0 \cdot 83$

$0 \cdot 17$

(b) Independent variables

Description

Mean

S.D.

Education of the household head (years; continuous)

Age of the household head (years; continuous)

Farm income (Ethiopian currency; continuous)

Non-farm income (Ethiopian currency; continuous)

Information on climate (dummy: 1 if available otherwise 0)

Farmer to farmer extension (dummy: 1 if occurs otherwise 0 )

Number of relatives in Got (village; continuous)

Local agro ecology is Kola (lowland) (dummy: 1 if Kola otherwise 0)

Local agro ecology is Dega (highland) (dummy: 1 if Dega otherwise 0)

\begin{tabular}{cc}
$1 \cdot 7$ & $2 \cdot 8$ \\
$44 \cdot 3$ & $12 \cdot 6$ \\
4375 & 7019 \\
218 & 791 \\
$0 \cdot 4$ & $0 \cdot 5$ \\
$0 \cdot 5$ & $0 \cdot 5$ \\
$13 \cdot 4$ & $19 \cdot 4$ \\
$0 \cdot 3$ & $0 \cdot 4$ \\
$0 \cdot 3$ & $0 \cdot 4$ \\
\hline
\end{tabular}

subsequently asked if they had responded through adaptation to reduce the negative impacts of climate change and 0.58 indicated that they have adopted one of the major adaptation options identified through the survey. These include planting trees, soil conservation, use of different crop varieties, changing planting dates and irrigation (Fig. 3). Farmers who perceived climate change but failed to adapt gave many reasons as barriers to adaptation, which included lack of information on adaptation methods, lack of money, shortage of labour, shortage of land and poor potential for irrigation.

The Heckman probit model was run and tested for its appropriateness over the standard probit model (i.e. a probit model that does not account for selection). The results indicated the presence of sample selection problem (dependence of the error terms from the outcome and selection models) justifying the use of Heckman probit model with rho significantly different from zero (Wald $\chi^{2}=10 \cdot 84$, with $P=0 \cdot 001$ ). 

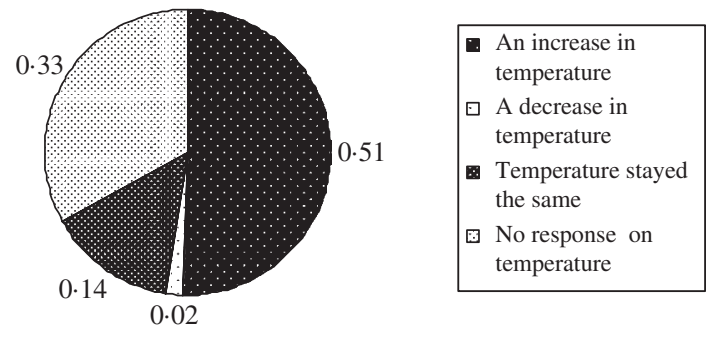

Fig. 1. Farmers' perception of long-term temperature changes.

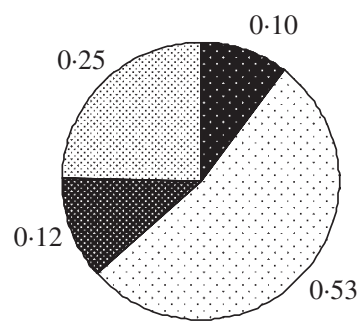

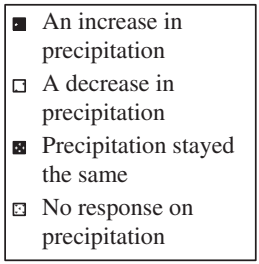

Fig. 2. Farmers' perception of long-term precipitation changes.

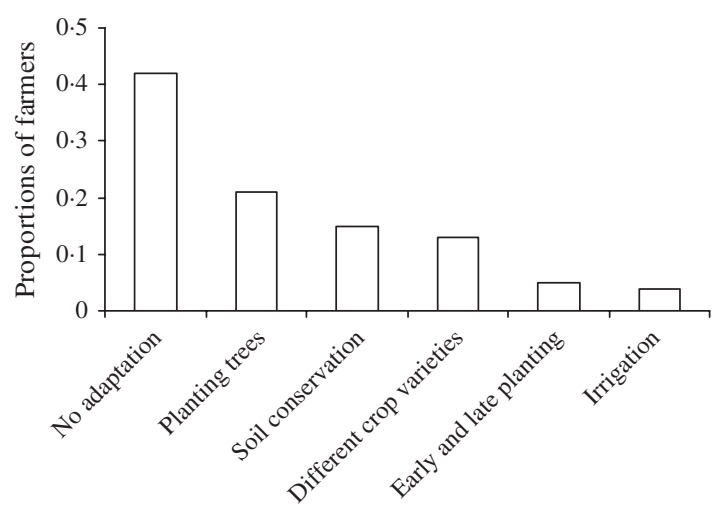

Fig. 3. Farmers' adaptation strategies.

Moreover, the likelihood function of the Heckman probit model was significant (Wald $\chi^{2}=86 \cdot 45$, with $P<0.001$ ), showing its strong explanatory power. Additionally, results show that most of the explanatory variables and their marginal values are statistically significant at $P<0.05$ and generally in the directions that would be expected (Table 3). The calculated marginal effects measure the expected changes in the probability of both perception of climate change and adaptation with respect to a unit change in an independent variable.

The results from the selection model, which analyses the factors affecting the perception of climate change, indicate that age of the head of the household, farm income, information on climate change, farmto-farm extension, number of relatives in a Got and agro-ecological settings affect the perception of climate change positively.

The results from the outcome model, which analyses the factors affecting adaptation, indicated that most of the explanatory variables affected the probability of adaptation as expected, except the farm size. Variables that positively and significantly influenced adaptation to climate change include education of the head of the household, the household size, whether the head of the household was male, livestock ownership, advice received on crop and livestock production and the availability of credit and temperature. However, larger farm size and high annual average precipitation were negatively related to adaptation.

\section{DISCUSSION}

Farmers should be able to adapt in order to reduce the negative impact of climate change. Adaptation to climate change is a two-step process which requires that farmers perceive climate change in the first step and respond to changes in the second step through adaptation. Different socio-economic and environmental factors affect the abilities to perceive and adapt to climate change.

Unlike the prior expectations, farmers living in dega (highlands) perceived more change in climate than farmers in Kola (lowland) or Woinadega (mid-land). This could either be associated with the recent drought (year 2002), with or could be linked to various environmental changes that cause reduced water availability (Meze-Hausken 2004). It might also be linked to various problems such as soil erosion, which reduces yield, or population pressure, which increases demand for food.

The fact that increasing household size increases the likelihood of adaptation is probably because large family size is normally associated with a higher labour endowment, which would enable a household to accomplish various agricultural tasks especially during peak seasons (Croppenstedt et al. 2003). Male-headed households often have a higher probability of adopting agricultural technologies (Buyinza \& Wambede 2008) and here adapted better to climate change. The incidence of adaptation to climate change increased with temperature, as has also been shown by Kurukulasuriya \& Mendelsohn (2006).

The probable reason for the negative relationship between adaptation and farm size could be due to the fact that adaptation is plot-specific. This means that it is not the size of the farm, but the specific characteristics of the farm that dictates the need for a specific adaptation method to climate change. Thus, future research that accounts for farm characteristics could reveal more information about factors 
Table 3. Results of the Heckman probit selection model

\begin{tabular}{|c|c|c|c|c|c|c|c|c|}
\hline \multirow[b]{3}{*}{ Explanatory variables } & \multicolumn{4}{|c|}{ Adaptation model } & \multicolumn{4}{|c|}{ Selection model } \\
\hline & \multicolumn{2}{|c|}{ Regression } & \multicolumn{2}{|c|}{ Marginal values } & \multicolumn{2}{|c|}{ Regression } & \multicolumn{2}{|c|}{ Marginal values } \\
\hline & Coefficients & $\begin{array}{c}P- \\
\text { value }\end{array}$ & Coefficients & $\begin{array}{c}P- \\
\text { value }\end{array}$ & Coefficients & $\begin{array}{c}P- \\
\text { value }\end{array}$ & Coefficients & $\begin{array}{c}P- \\
\text { value }\end{array}$ \\
\hline Education & $0 \cdot 061$ & 0.017 & $0 \cdot 019$ & 0.017 & $0 \cdot 021$ & 0.393 & 0.005 & $0 \cdot 388$ \\
\hline Household size & $0 \cdot 058$ & $0 \cdot 053$ & $0 \cdot 018$ & $0 \cdot 051$ & & & & \\
\hline $\begin{array}{l}\text { Gender of the household } \\
\text { head }\end{array}$ & $0 \cdot 580$ & $0 \cdot 010$ & $0 \cdot 177$ & $0 \cdot 012$ & & & & \\
\hline Age of the household head & & & & & $0 \cdot 018$ & 0.000 & $0 \cdot 004$ & $0 \cdot 000$ \\
\hline Farm income & & & & & $0 \cdot 0000566$ & $0 \cdot 000$ & $0 \cdot 000013$ & $0 \cdot 000$ \\
\hline Non-farm income & $0 \cdot 000149$ & $0 \cdot 143$ & $0 \cdot 0000455$ & $0 \cdot 144$ & $-0 \cdot 000011$ & $0 \cdot 911$ & $-0 \cdot 00000254$ & $0 \cdot 911$ \\
\hline Livestock ownership & $1 \cdot 012$ & $0 \cdot 003$ & $0 \cdot 309$ & $0 \cdot 004$ & & & & \\
\hline $\begin{array}{l}\text { Extension on crop and } \\
\text { livestock }\end{array}$ & $1 \cdot 024$ & $0 \cdot 000$ & $0 \cdot 303$ & $0 \cdot 000$ & & & & \\
\hline $\begin{array}{l}\text { Information on climate } \\
\text { change }\end{array}$ & & & & & $0 \cdot 372$ & $0 \cdot 014$ & $0 \cdot 080$ & $0 \cdot 009$ \\
\hline $\begin{array}{l}\text { Farmer to farmer } \\
\text { extension }\end{array}$ & & & & & $0 \cdot 707$ & $0 \cdot 000$ & $0 \cdot 155$ & $0 \cdot 000$ \\
\hline Credit availability & $0 \cdot 479$ & $0 \cdot 003$ & $0 \cdot 131$ & $0 \cdot 001$ & & & & \\
\hline Number of relatives in Got & & & & & $0 \cdot 011$ & 0.038 & 0.003 & $0 \cdot 035$ \\
\hline Farm size in hectares & $-0 \cdot 140$ & $0 \cdot 011$ & $-0 \cdot 043$ & $0 \cdot 013$ & & & & \\
\hline Distance to output market & $-0 \cdot 053$ & $0 \cdot 310$ & $-0 \cdot 016$ & $0 \cdot 310$ & & & & \\
\hline Distance to input market & $0 \cdot 075$ & $0 \cdot 143$ & $0 \cdot 023$ & $0 \cdot 141$ & & & & \\
\hline Local agro ecology Kola & & & & & $0 \cdot 047$ & $0 \cdot 761$ & $0 \cdot 011$ & $0 \cdot 757$ \\
\hline Local agro ecology Dega & & & & & $0 \cdot 849$ & $0 \cdot 000$ & $0 \cdot 155$ & $0 \cdot 000$ \\
\hline Temperature & $0 \cdot 178$ & $0 \cdot 000$ & $0 \cdot 055$ & $0 \cdot 000$ & & & & \\
\hline Precipitation & $-0 \cdot 012$ & $0 \cdot 000$ & $-0 \cdot 004$ & $0 \cdot 000$ & & & & \\
\hline Constant & $-3 \cdot 670$ & $0 \cdot 000$ & & & $-0 \cdot 821$ & $0 \cdot 001$ & & \\
\hline Total observations & 608 & & & & & & & \\
\hline Censored & 126 & & & & & & & \\
\hline Uncensored & 482 & & & & & & & \\
\hline $\begin{array}{l}\text { Wald Chi square } \\
\text { (Zero slopes) }\end{array}$ & $86 \cdot 45, P<0$ & 001 & & & & & & \\
\hline $\begin{array}{l}\text { Wald Chi square } \\
\text { (independent equations) }\end{array}$ & $10 \cdot 84, P=0$ & 001 & & & & & & \\
\hline
\end{tabular}

dictating adaptation to climate change at the farm or plot level. The negative relationship between average annual precipitation and adaptation probably reflects that increasing precipitation relaxes the constraint imposed by increasing temperature on crop growth.

Most of the above factors identified as affecting the perception of and adaptation to climate change in the Nile basin of Ethiopia are directly related to the development of institutions and infrastructure. This is in line with the current Ethiopian government policy of poverty reduction and accelerated development through investment in education to enhance human capacity, infrastructure, such as roads and telecommunications, and institutions, such as credit facilities both in urban and rural areas (Ministry of Finance and Economic Development: MoFED 2007).
Although the current effort by the government assists in enhancing adaptive capacity, more needs to be done in terms of effective adaptation to climate change to protect the already weak agricultural sector. Future policy could focus on creating awareness of climate change and facilitating the development and adoption of adaptation technologies.

This work was supported by the Federal Ministry for Economic Cooperation and Development, Germany, under the project 'Food and Water Security Under Global Change: Developing Adaptive Capacity with a Focus on Rural Africa', which forms part of the Consultative Group on International Agricultural Research (CGIAR), Challenge Program on Water and Food (CPWF). The authors would like to thank Wisdom Akpalu, 
Elizabeth Bryan and Edward Keto for reviewing this report and giving constructive comments. Mahmud Yesuf, Tekie Alemu, Tim Sulser and Minale Kasie contributed much to this research through participating in pre-test and adjusting the questionnaire accordingly.

\section{REFERENCES}

Admassie, A. \& Adenew, B. (2007). Stakeholders' Perceptions of Climate Change and Adaptation Strategies in Ethiopia. EEA Research Report. Addis Ababa, Ethiopia: Ethiopians Economic Association.

Akter, S. \& Bennett, J. (2009). Household Perceptions of Climate Change and Preferences for Mitigation Actions: the Case of the Carbon Pollution Reduction Scheme in Australia. Environmental Economics Research Hub Research Report No. 19. Canberra, Australia: Australian National University. Available online at http://www. crawford.anu.edu.au/research_units/eerh/pdf/EERH_RR19. pdf. (verified 26 July 2010).

Alene, A. D. (2003). Improved production technology and efficiency of small holder farmers in Ethiopia: extended parametric and non-parametric approaches to production efficiency analysis. PhD Thesis, University of Pretoria, South Africa.

Belay, K. (2003). Agricultural extension in Ethiopia: the case of participatory demonstration and training extension system. Journal of Social Development in Africa 18, 49-83.

Belay, K., Beyene, F. \& Manig, W. (2005). Coping with drought among pastoral and agro-pastoral communities in eastern Ethiopia. Journal of Rural Development 28, 185-210.

Bradshaw, B., Dolan, H. \& Smit, B. (2004). Farm-level adaptation to climatic variability and change: crop diversification in the Canadian Prairies. Climatic Change 67, 119-141.

BuyinzA, M. \& WAmbede, N. (2008). Extension of agroforestry technology adoption: mixed intercropping of crotalaria (Crotaloria grahamiana) and maize (Zea mays L.) in Kabale District, Uganda. Environmental Research Journal 2, 131-137.

CSA (Central Statistics Authority). (2005). 2003 National Statistics (Abstract). Addis Ababa, Ethiopia: CSA.

Croppenstedt, A., Demeke, M. \& Meschi, M. M. (2003). Technology adoption in the presence of constraints: the case of fertilizer demand in Ethiopia. Review of Development Economics 7, 58-70.

Deressa, T. T. \& Hassan, R. M. (2009). Economic impact of climate change on crop production in Ethiopia: evidence from cross-section measures. Journal of African Economies 18, 529-554.

Deressa, T. T., Hassan, R. M., Ringler, C., Alemu, T. \& Yesuf, M. (2009). Determinants of farmers' choice of adaptation methods to climate change in the Nile Basin of Ethiopia. Global Environmental Change 19, 248-255.

Devereux, S. (2000). Food Security in Ethiopia: A Discussion Paper for DFID. Sussex, UK: Institute for Development Studies.

Diggs, D. M. (1991). Drought experience and perception of climatic change among Great Plains farmers. Great Plains Research: A Journal of Natural and Social Sciences 1, 114-132.

Dixon, J., Gulliver, A. \& Gibbon, D. (2001). Farming Systems and Poverty: Improving Farmers' Livelihoods in a
Changing World. Rome and Washington, DC: FAO and World Bank.

Edwards-Jones, G., Plassmann, K. \& Harris, I. M. (2009). Carbon footprinting of lamb and beef production systems: insights from an empirical analysis of farms in Wales, UK. Journal of Agricultural Science, Cambridge 147, 707-719.

FüssEL, H. (2007). Vulnerability: a generally applicable conceptual framework for climate change research. Global Environmental Change 17(2), 155-167.

Gbetibouo, G. A. (2009). Understanding Farmers' Perceptions and Adaptations to Climate Change and Variability: The Case of the Limpopo Basin, South Africa. IFPRI Discussion Paper No. 00849. Washington, DC: IFPRI. Available online at: http:/www.ifpri.org/publication/ understanding-farmers-perceptions-and-adaptationsclimate-change-and-variability (verified 14 June 2010).

Hageback, J., Sundberg, J., Ostwald, M., Chen, D., Yun, X. \& Knutsson, P. (2005). Climate variability and land use change in Danagou, watershed, China - examples of small scale farmers' adaptation. Climatic Change 72, 189-212.

Hassan, R. \& Nhemachena, C. (2008). Determinants of climate adaptation strategies of African farmers: multinomial choice analysis. African Journal of Agricultural and Resource Economics 2, 83-104.

Heckman, J. J. (1976). The common structure of statistical models of truncation, sample selection and limited dependent variables and a simple estimator for such models. Annals of Economic and Social Measurement 5, 475-492.

Houghton, J. T., Ding, Y., Griggs, D. J., Noguer, M., VAN DER Linden, P. J., DAi, X., Maskell, K. \& Johnson, C.A. (2001). Climate Change 2001: The Physical Basis. Contribution of Working Group I to the Third Assessment Report of the Intergovernmental Panel on Climate Change, 2001. Cambridge, UK: Cambridge University Press.

IAC (Inter ACADEMy Council). (2004). Realizing the Promise and Potential of African Agriculture. Amsterdam, The Netherlands: Inter Academy Council.

Isham, J. (2002). The effect of social on fertiliser adoption: evidence from rural Tanzania. Journal of African Economies 11, 39-60.

IshayA, S. \& ABAJE, I. B. (2008). Indigenous people's perception of climate change and adaptation strategies in Jema's local government area of Kaduna State, Nigeria. Journal of Geography and Regional Planning 1, 138-143.

Kaliba, A. R. M., Verkuijl, H. \& Mwangi, W. (2000). Factors affecting adoption of improved seeds and use of inorganic fertilizers for maize production in the intermediate and lowland zones of Tanzania. Journal of Agricultural and Applied Economics 32, 35-48.

Kurukulasuriya, P. \& Mendelsohn, R. (2006). Crop Selection: Adapting to Climate Change in Africa. CEEPA 
Discussion Paper No. 26. Pretoria, South Africa: Centre for Environmental Economics and Policy in Africa.

Kurukulasuriya, P. \& Mendelsohn, R. (2008). A Ricardian analysis of the impact of climate change on African cropland. African Journal of Agricultural and Resource Economics 2, 1-23.

Lautze, S., Aklilu, Y., Raven-Roberts, A., Young, H., Kebede, G. \& Leaning, J. (2003). Risk and Vulnerability in Ethiopia: Learning from the Past, Responding to the Present, Preparing for the Future. Report for the U.S. Agency for International Development. Addis Ababa, Ethiopia: USAID.

Leiserowitz, A. (2006). Climate change risk perception and policy preferences: the role of affect, imaginary, and values. Climatic Change 77, 45-72.

Maddison, D. (2006). The Perception of and Adaptation to Climate Change in Africa. CEEPA Discussion Paper No. 10. Pretoria, South Africa: Centre for Environmental Economics and Policy in Africa.

Maraseni, T. N., Mushtaq, S. \& Maroulis, J. (2009). Greenhouse gas emissions from rice farming inputs: a cross-country assessment. Journal of Agricultural Science, Cambridge 147, 117-126.

Maraseni, T. N., Cockfield, G. \& Maroulis, J. (2010). An assessment of greenhouse gas emissions: implications for the Australian cotton industry. Journal of Agricultural Science, Cambridge 148, 501-510.

McBride, W. D. \& Daberkow, S. G. (2003). Information and the adoption of precision farming technologies. Journal of Agribusiness 21, 21-38.

Mertz, O., Mbow, C., Reenberg, A. \& Diouf, A. (2009). Farmers' perceptions of climate change and agricultural adaptation strategies in rural Sahel. Environmental Management 43, 804-816.

Meze-Hausken, E. (2004). Contrasting climate variability and meteorological drought with perceived drought and climate change in northern Ethiopia. Climate Research 27, $19-31$.

Mitchell, T. D. \& Jones, P. D. (2005). An improved method of constructing a database of monthly climate observations and associated high-resolution grids. International Journal of Climatology 25, 693-712.

MOFED (MINISTRY OF FINANCE AND ECONOMIC Development). (2007). Ethiopia: Building on Progress: A Plan for Accelerated and Sustained Development to End Poverty (PASDEP). Annual Progress Report. Addis Ababa, Ethiopia: MOFED.

Nhemachena, C. (2009). Agriculture and future climate dynamics in Africa: impacts and adaptation options. Ph.D. Thesis, Department of Agricultural Economics, Extension, and Rural Development, University of Pretoria, South Africa.

Nhemachena, C. \& Hassan, R. M. (2007). Micro-Level Analysis of Farmers' Adaptation to Climate Change in Southern Africa. IFPRI Discussion Paper No. 714.
Washington, DC: International Food Policy Research Institute.

Norris, P. E. \& BAtie, S. S. (1987). Virginia farmers' soil conservation decisions: an application of Tobit analysis. Southern Journal of Agricultural Economics 19, 79-90.

Pryanishnikov, I. \& Zigova, K. (2003). Multinomial logit models for Austrian labour market. Austrian Journal of Statistics 32, 267-282.

Sampei, Y. \& Aoyagi-Usui, M. (2009). Mass-media coverage, its influence on public awareness of climate-change issues, and implications for Japan's national campaign to reduce greenhouse gas emissions. Global Environmental Change 19, 203-212.

Semenza, J. C., Hall, D. E., Wilson, D. J., Bontempo, B. D., Sailor, D. J. \& George, L. A. (2008). Public perception of climate change voluntary mitigation and barriers to behaviour change. American Journal of Preventive Medicine 35, 479-487.

Seo, S. N. \& Mendelsohn, R. O. (2006). Climate Change Adaptation in Africa: a Microeconomic Analysis of Livestock Choice. CEEPA Discussion Paper No. 19. Pretoria, South Africa: Centre for Environmental Economics and Policy in Africa.

SJoberG, L. (2000). Factors in risk perception. Risk Analysis 20, $1-11$.

StrzepeK, K. \& McCluskey, A. (2006). District Level Hydro-climatic Time Series and Scenario Analysis to Assess the Impacts of Climate Change on Regional Water Resources and Agriculture in Africa. CEEPA Discussion Paper 13. Pretoria, South Africa: Centre for Environmental Economics and Policy in Africa.

TADEge, A. (2007). Climate Change National Adaptation Program of Action (NAPA) of Ethiopia. Addis Ababa, Ethiopia: NMS (National Meteorological Agency: Federal Democratic Republic of Ethiopia, Ministry of Water Resources).

Thomas, D. S. G., Twyman, C., Osbahr, H. \& Hewitson, B. (2007). Adaptation to climate change and variability: farmer responses to intra-seasonal precipitation trends in South Africa. Climatic Change 83, 301-322.

VAN de Ven, W. P. M. M. \& Van Praag, B. M. S. (1981). The demand for deductibles in private health insurance: a probit model with sample selection. Journal of Econometrics 17, 229-252.

Vedwan, N. \& RhoAdes, R. E. (2001). Climate change in the Western Himalayas of India: a study of local perception and response. Climate Research 19, 109-117.

WU, J. J. \& BAвсоск, B. A. (1998). The choice of tillage, rotation, and soil testing practices: economic and environmental implications. American Journal of Agricultural Economics 80, 494-511.

YIRGA, C. T. (2007). The dynamics of soil degradation and incentives for optimal management in Central Highlands of Ethiopia. PhD Thesis, Department of Agricultural Economics, Extension and Rural Development, University of Pretoria, South Africa. 